\title{
PENGARUH PELATIHAN MENGGUNAKAN MODUL CARA MENYIKAT GIGI TERHADAP PENGETAHUAN GURU SD UNGGUL SAKTI KOTA JAMBI
}

Asio*

\begin{abstract}
ABSTRAK
Pelatihan guru sekolah dasar dalam dibidang kesehatan merupakan sasaran utama promosi kesehatan, masyarakat sebagai sasaran primer (primary target) promosi kesehatan harus diberdayakan agar mereka mau dan maтри memelihara dan meningkatkan kesehatan mereka sendiri. Peningkatan peran serta dan ketrampilan guru dalam pelayanan kesehatan sesuai dengan lingkup pendelegasian wewenang, agar guru mampu berperan serta aktif dalam bimbingan anak didiknya dalam peningkatan kebersihan gigi dan mulut, Tujuan penelitian untuk mengetahui pengaruh peningkatan pelatihan menggunakan modul cara menyikat gigi terhadap pengetahuan guru SD Unggul Sakti Kota Jambi.

Jenis penelitian adalah Penelitian eksperimen kuasi dengan rancangan pre-test and post-test control group design responden berjumlah 18 orang guru kelas SD Unggul Sakti Kota Jambi, (kelompok eksperimen) dan responden 18 orang guru SD Sari Putra sebagai (kelompok kontrol). Variabel penelitian pengetahuan, cara pengambilan data mengisi kuesioner tentang pengetahuan guru SD cara menyikat gigi sebelum dan sesudah pelatihan menggunakan modul cara menyikat gigi.

Hasil penelitian dari Hasil uji beda selisih Wilcoxon menunjukan, ada perbedaan yang signifikan sesudah pelatihan 18 responden guru SD Unggul Sakti Kota Jambi nilai Median (Min-Mak) 20 (19-20) (kelompok eksperimen) dan sesudah observasi nilai Median (Min-Mak) 8.5 (7-14). Hasil uji statistik nilai p < 0,001 maka dapat disimpulkan ada pengaruh pelatihan menggunakan modul cara menyikat gigi terhadap pengetahuan guru SD Unggul Sakti Kota Jambi.
\end{abstract}

Kata kunci : Pelatihan Guru SD, Pengetahuan, Cara Menyikat Gigi

\begin{abstract}
Elementary school health training is a main objective of health promotion. Society, which is the health promotion primary target must be empowered to accept and able to maintain and develop their own health. The increase of teacher's participation and skill in health service is in accordance with authority delegation scope, that teachers are able to play active role in guiding their students in increasing dental and oral hygiene. The purpose of the research is to find out the impact of increasing the training using how to brush teeth module towards SD Unggul Sakti Kota Jambi teachers' knowledge.

It is a quasi experiment with pre-test and post-test control group design. The respondents are 18 Elementary school Unggul Sakti Jambi city teachers as control group and 18 Elementary School Sari Putra teachers as control group. For the knowledge variable, the data collection is by filling questionaire about elementary school teacher knowledge about brushing teeth before and after the training using brushing teeth module. The data analyzed with Wilcoxon test.

Research result shows that $p<0,001$, which means that there is a significant differentiation of teacher's knowledge between before and after the training. Median value (min-Max) 20 (19-20) (experiment group) and after the observation, the median value (Min-Max) 8.5 (7-14). So, it can be concluded that there is an impact of training using brushing teeth module towards SD Unggul Sakti Kota Jambi teacher's knowledge.
\end{abstract}

Keywords : elementary teacher training, knowledge, how to brush teeth

\footnotetext{
${ }^{\bar{*})}$ Dosen Jurusan Keperawatan Gigi Poltekkes Kemenkes Jambi

凶:asiojambi@gmail.com
} 


\section{PENDAHULUAN}

Perilaku benar dalam menyikat gigi ditemukan sebagian besar penduduk Indonesia menyikat gigi saat mandi pagi maupun mandi sore $(76,6 \%)$, menyikat gigi dengan benar adalah setelah makan pagi dan sebelum tidur malam, untuk Indonesia ditemukan hanya (2,3\%). indeks DMF-T menggambarkan tingkat keparahan kerusakan gigi. Indeks $D M F-T$ prevalensi nasional indek $D M F-T$ adalah 4,6, sebanyak 15 propinsi memiliki diatas prevalensi nasional indeks $D M F-T$ lebih tinggi pada perempuan $(5,0)$ dibanding laki-laki (Kemenkes, 2014).

Pelatihan guru sekolah dasar dalam dibidang kesehatan merupakan sasaran utama promosi kesehatan, masyarakat sebagai sasaran primer (primary target) promosi kesehatan harus diberdayakan agar mereka mau dan mampu memelihara dan meningkatkan kesehatan mereka sendiri. Peningkatan peran serta dan keterampilan guru dalam pelayanan kesehatan sesuai dengan lingkup pendelegasian wewenang, agar guru mampu berperan serta aktif dalam bimbingan anak didiknya dalam peningkatan kebersihan gigi dan mulut (www.guru pintar.ut.ac.id, 2015).

Filosofi pelatihan guru dengan memperhatikan prinsip belajar orang dewasa (adult learning) bahwa selama pelatihan peserta berhak untuk didengarkan dan dihargai pengalamannya, dipertimbangkan setiap ide dan pendapatnya sejauh berada didalam konteks pelatihan, belajar sambil berbuat (learning by doing) dari materi pelatihan (Fidishun, 2000).

Berdasarkan laporan pelayanan asuhan keperawatan gigi dan mulut di sekolah dasar binaan Jurusan Keperawatan Gigi Poltekkes Kemenkes Jambi di sekolah dasar Unggul Sakti tahun 2013, menunjukkan bahwa rata-rata OHIS (Oral Hygiene Indeks-Symplified) sebesar 46,2\% kriteria buruk.

Berdasarkan hasil wawancara kepada Kepala SD Unggul Sakti Kota Jambi, diketahui benar telah dilakukan pelayanan asuhan kesehatan gigi dan mulut oleh mahasiswa JKG Poltekkes Kemenkes Jambi pada setiap semester V secara rutin satu kali sejak tahun 2009 sampai saat ini dalam bentuk promotif dan preventif pemeriksaan dan penyuluhan serta sikat gigi massal tetapi belum ada upaya evaluasi. Maka guru perlu diberi internvensi pengetahuan tentang kesehatan gigi dan mulut untuk meningkatkan derajat kesehatan gigi dan mulut guru dan murid SD Unggul Sakti.

Berdasarkan data sekunder tersebut diatas, peneliti menganalisa secara eksploratoris ada masalah yang urgent untuk diatasi berupa intervensi dari peneliti dengan judul yaitu "Pengaruh Pelatihan Menggunakan Modul Cara menyikat Gigi Terhadap Pegetahuan Guru SD Unggul Sakti Kota Jambi. Tercakup dalam suatu siklus kegiatan tertentu PDCA (Plan, Do, Check, Action) (Azwar. A, 1996)

\section{BAHAN DAN CARA KERJA}

Jenis Penelitian adalah penelitian eksperimen kuasi dengan rancangan pre-test and post-test control group design, responden berjumlah 18 orang guru kelas SD Unggul Sakti Kota Jambi, (kelompok eksperimen) dan 18 orang guru SD Sari Putra sebagai (kelompok kontrol).

Cara pengumpulan data, responden mengisi kuesioner tentang pengetahuan cara menyikat gigi sebelum dan sesudah pelatihan menggunakan modul cara menyikat gigi. Data yang sudah dikumpulkan diolah melalui tahapan editing, coding, entry data, dan cleaning data (DepKes. RI, 2000)

Penyajian hasil penelitian diuraikan sesuai dengan tujuan penelitian yaitu mengetahui pengaruh peningkatan pelatihan menggunakan modul cara menyikat gigi terhadap pengetahuan guru SD Unggul Sakti Kota Jambi. Analisa data menggunakan analisis univariat dan bivariat (uji hipotesis komparatif kelompok berpasangan). 


\section{HASIL DAN PEMBAHASAN}

Tabel 1. Presentasi Tingkat Pengetahuan Sebelum dan Sesudah Pelatihan Guru SD Unggul Sakti Jambi

\begin{tabular}{lcccc}
\hline Tingkat Pengetahuan & \multicolumn{2}{c}{$\begin{array}{c}\text { Frekuensi } \\
\text { Sebelum }\end{array}$} & \multicolumn{2}{c}{$\begin{array}{c}\text { Frekuensi } \\
\text { Sesudah }\end{array}$} \\
\hline & $\mathrm{n}$ & $\%$ & $\mathrm{n}$ & $\%$ \\
\hline Kurang baik & 1 & 5,6 & 0 & 0 \\
\hline Baik & 17 & 94,4 & 18 & 100,0 \\
\hline Total & 18 & 100,0 & 18 & 100,0 \\
\hline
\end{tabular}

Tabel 1 menjelaskan presentase pengetahuan pelatihan guru SD Unggul Sakti Kota Jambi kriteria kurang baik sebelum pelatihan $5,6 \%$ setelah pelatihan responden guru menunjukkan hasil $100 \%$ baik atau pengetahuannya meningkat (Susetyo .B, 2010).

Pelatihan merupakan serangkaian aktivitas yang dirancang untuk meningkatkan keahlian-keahlian, pengetahuan, pengalaman, ataupun perubahan sikap seorang individu. Pelatihan berkenaan dengan perolehan keahlian-keahlian atau pengetahuan tertentu, peranan pelatih atau fasilitator dalam proses belajar pendidikan orang dewasa adalah membantu, mendorong, mempermudah dan mengembangkan terjadinya proses belajar mandiri dengan menciptakan dan mengembangkan suasana yang kondusif (www.guruonline.com, 2012). Pelayanan asuhan kesehatan gigi dan mulut adalah pelayanan kesehatan gigi dan mulut yang terencana, ditujukan pada kelompok tertentu, yang dapat diikuti dalam satu kurun waktu tertentu, diselenggarakan secara berkesinambungan untuk mencapai tujuan kesehatan gigi dan mulut yang optimal (DepKes, 1995).

Promosi kesehatan (Health Promotion) adalah untuk meningkatkan derajat kesehata gigi dengan memilih makanan yang dapat menyehatkan gigi, mengatur pola makanan yang mengandung gula (Erijulianti. E dkk, 2002).

Bimbingan teknis kepada guru dalam rangka peningkatan peran serta dan keterampilan dalam pelaksanaan pelayanan kesehatan sesuai lingkup pendelegasian wewenang (DepKes RI 1994).

UKGS Inovatif adalah penerapan ilmu pengetahuan dan teknologi terkini yaitu teknologi motivasi untuk membangkitkan peran serta masyarakat (guru SD) dan teknologi pencegahan dan perlindungan gigi untuk memotong mata rantai karies (Kemenkes RI, 2012).

Lima konsep Proses keperawatan gigi (Dental Hygiene Process of Care) meliputi Penilaian Assesmet (Data), Diagnosa, Planning, Implementasi, Evaluasi (Wilskin, 2004).

Tabel 2. Test of Normality

\begin{tabular}{cccc}
\hline & \multicolumn{3}{c}{ Shapiro-Wilk } \\
\hline & Statistic & Df & Sig \\
\hline $\begin{array}{c}\text { Penegtahuan Guru Sebelum } \\
\text { Intervensi }\end{array}$ & .728 & 18 & 0,000 \\
$\begin{array}{c}\text { Pengetahuan Guru Sesudah } \\
\text { Intervensi }\end{array}$ &, 457 & 18 & 0,000 \\
\hline
\end{tabular}

Tabel 2 di atas diperoleh nilai $\mathrm{p}=0,000$ karena nilai $\mathrm{p}<0,005$ maka diambil kesimpulan distribusi data tidak normal. Analisa uji beda selisih analisa d Uji Wilcoxon.

Tabel 3. Nilai p-value, Rerata, Simpang Baku dan Alpha Pengaruh Pelatihan Menggunakan Modul Menyikat Gigi Terhadap Pengetahuan Guru SD Unggul Sakti Kota Jambi

\begin{tabular}{ccccc}
\hline Pengetahuan & n & Rerata & $\begin{array}{l}\text { Simp } \\
\text { Baku }\end{array}$ & $\mathbf{p}$ \\
\hline $\begin{array}{c}\text { Sebelum } \\
\text { Penyuluhan }\end{array}$ & 18 & 6,50 & 0,618 & 0,001 \\
\hline $\begin{array}{c}\text { Pengetahuan } \\
\text { Setelah } \\
\text { Penyuluhan }\end{array}$ & 18 & & & \\
\hline
\end{tabular}

Tabel 3 diketahui bahwa nilai rerata 6,50 simpang baku 0,618 , dengan nilai $\mathrm{p}$ value 0,001 artinya ada pengaruh pelatihan menggunakan modul cara menyikat gigi terhadap pengetahuan guru SD Unggul Sakti Kota Jambi.

Pelatihan guru sekolah dasar dalam bidang kesehatan merupakan sasaran utama promosi kesehatan, masyarakat sebagai sasaran primer (primary target) promosi kesehatan harus diberdayakan agar mereka 
mau dan mampu memelihara dan meningkatkan kesehatan mereka sendiri. Peningkatan peran serta dan keterampilan guru dalam pelayanan kesehatan sesuai dengan lingkup pendelegasian wewenang, agar guru mampu berperan serta aktif dalam bimbingan anak didiknya dalam peningkatan kebersihan gigi dan mulut (www.gurupintar.ut.ac.id, 2015).

Filosofi pelatihan pemberdayaan guru dengan memperhatikan prinsip belajar orang dewasa (adult learning) bahwa selama pelatihan peserta berhak untuk didengarkan dan dihargai pengalamannya, dipertimbangkan setiap ide dan pendapatnya sejauh berada didalam konteks pelatihan, belajar sambil berbuat (learning by doing) dari materi pelatihan (Fidishun, 2000).

\section{KESIMPULAN}

Berdasarkan penelitian ini dapat disimpulkan bahwa :

1. Presentase pengetahuan pelatihan guru SD Unggul Sakti Kota Jambi kriteria kurang baik sebelum pelatihan $5,6 \%$ setelah pelatihan guru menunjukkan hasil $100 \%$ baik atau pengetahuannya meningkat.

2. Nilai rerata 6,50 simpang baku 0,618 , dengan nilai $\mathrm{p}$-value 0,001 artinya ada pengaruh pelatihan menggunakan modul cara menyikat gigi terhadap pengetahuan guru SD Unggul Sakti Kota Jambi.

\section{SARAN}

Berdasarkan hasil penelitian, diharapkan untuk penelitian selanjutnya pengaruh modul menyikat gigi terhadap perilaku guru SD Unggul Sakti Kota Jambi dalam meningkatkan derajat kesehatan gigi dan mulut anak didiknya.

\section{DAFTAR PUSTAKA}

Azwar.A, 1996. Menjaga Mutu Pelayanan Kesehatan, Pustaka Sinar Harapan hal. 148
Ester.M, Wilkins, BS, RDH, DMD, 2004, Department of Periodontology Tufts University chool of Dental Medicine Boston Massachustts Clinical Practice of the dental Hygienist.

DepKes RI, 1994, Penuntun Pelaksanaan Usaha Kesehatan Gigi Sekolah.

Depkes RI, 2000, Direktorat Jenderal Pelayanan Medik Direktorat Kesehatan Gigi.

Depkes RI, 1995, Tata Kerja Pelayanan Asuhan Kesehatan Gigi dan Mulut di Puskesmas.

Fidishun, 2000 Adult Learning Theory and Principles) ttp:// www.qotfc. edu. au/ resource/ ?page $=65375$

Herijulianti.E dkk, 2002 Pendidikan Kesehatan Gigi. EGC.

Dahlan. S.M, 2012 Statistik Untuk Kedokteran dan Kesehatan Deskriptif, Bivariat dan Multivariat. Salemba Medika

Kemenkes RI. 2012, Pedoman Usaha Kesehatan Gigi Sekolah (UKGS).

--------------, 2014. Laporan Hasil Riskesdas 2013, Badan Penelitian dan Pengembangan Kesehatan Kemenkes RI. Jakarta.

Susetyo.B, 2010 Statika Analisis Data Penelitian PT Repika Aditama

www.guruonline.com, 2012. Analisis pengaruh pemberdayaan guru terhadap kinerjanya dalam meningkatkan kualitas pendidikan di sekolah 